\title{
STRICT LIABILITY FOR GATEKEEPERS: A REPLY TO PROFESSOR COFFEE
}

\author{
Frank PARTNOY*
}

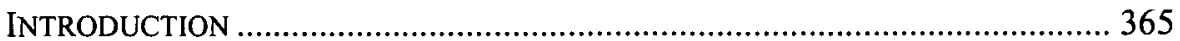

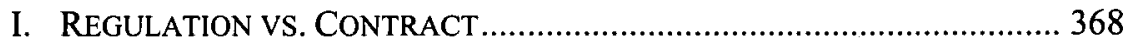

II. REVENUE MULTIPLE VS. PERCENTAGE OF DAMAGES ......................... 370

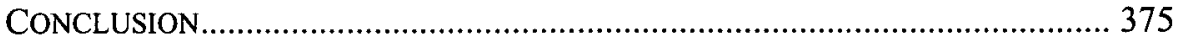

\section{INTRODUCTION}

In his contribution to this issue, Professor John C. Coffee, Jr. proposes a modified form of strict liability for gatekeepers (other than attorneys), ${ }^{1}$ which would convert gatekeepers into insurers but cap their insurance obligations based on a multiple of the highest annual revenues the gatekeepers recently had received from their wrongdoing clients. ${ }^{2}$ Professor Coffee argues that there are three practical differences between his proposal and the gatekeeper strict liability proposal I advanced in $2001:^{3}$ (1) his system is regulatory,

- Professor of Law, University of San Diego School of Law.

${ }^{1}$ Professor Coffee defines "gatekeeper" as "a reputational intermediary who provides verification or certification services to investors." John C. Coffee, Jr., Gatekeeper Failure and Reform: The Challenge of Fashioning Relevant Reforms, 84 B.U. L. REV. 301, 309 (2004) (defining "gatekeeper"). This definition is narrower than those many other scholars have used. See Reinier H. Kraakman, Corporate Liability Strategies and the Costs of Legal Controls, 93 YALE L.J. 857, 895-96 (1984); Reinier H. Kraakman, Gatekeepers: The Anatomy of a Third-Party Enforcement Strategy, 2 J.L. ECON. \& ORG. 53, 53 (1986) [hereinafter Kraakman, Gatekeepers] (defining gatekeepers as "private parties who are able to disrupt misconduct by withholding their cooperation from wrongdoers"). Professor Ronald Gilson has even suggested that "gatekeeper" and "reputational intermediary" may have entirely different meanings. See Ronald Gilson, Remarks at the Washington University Law School and Institute for Law and Economic Policy Corporate Accountability Symposium (Mar. 9-10, 2001) (transcript on file with author). For purposes of this essay, I will adopt Professor Coffee's definition, and will exclude attorneys from the strict liability analysis and focus primarily on accounting firms, as he does.

${ }^{2}$ See Coffee, supra note 1, at 349-50.

${ }^{3}$ My proposal would

impose strict liability on gatekeepers for material misstatements and omissions in offering documents and remove any due diligence-based defenses from securities regulation. For example, Congress should amend Section 11 to impose strict liability not only on the issuer and directors, but also on all experts. Congress should add an additional provision to enable experts to specify the range of liability as a percentage of 
whereas mine is contractual; (2) his system uses a revenues multiple as a minimum floor, whereas mine uses a percentage of damages; and (3) his system would be less likely than mine to lead to gatekeeper bankruptcies. ${ }^{4}$

This article will respond briefly to Professor Coffee's argument and defend my own. But first, I want to note that both proposals mark a radical shift in the scholarship addressing gatekeeper liability. In this area, Professor Coffee and I are very much in agreement. Until recently, scholarship on gatekeepers had focused on reputation-not regulation or civil liability-as the key limitation on gatekeeper behavior. Indeed, many scholars have argued that liability should not be imposed on gatekeepers in various contexts, ${ }^{5}$ and that reputationrelated incentives alone would lead gatekeepers to screen against fraudulent transactions and improper disclosure in an optimal way, even in the absence of liability. ${ }^{6}$ According to these views, gatekeeper liability would be appropriate only in limited instances, when issuer liability was suboptimal. ${ }^{7}$

In contrast, Professor Coffee and I argue that reputational pressures alone do not create adequate incentives for issuers to disclose material facts, or for gatekeepers to certify that issuers have done so. Along these lines, several scholars recently have argued that gatekeepers should play an insuring role more than a policing role. ${ }^{8}$ There are both strong empirical and theoretical bases for these arguments.

If reputational markets were efficient, gatekeepers would screen issuers in an optimal way to safeguard their reputations, even without the prospect of legal liability, just as issuers would make optimal disclosures. ${ }^{9}$ However, as an

the issuer's liability, subject to a specified minimum percentage.

Frank Partnoy, Barbarians at the Gatekeepers?: A Proposal for a Modified Strict Liability Regime, 79 WASH. U. L.Q. 491, 540 (2001) (proposing gatekeeper strict liability as an alternative to a due-diligence regime).

${ }^{4}$ Coffee, supra note 1 , at $350-51$ (stating the three ways in which the proposals of this author and Professor Coffee differ).

5 See, e.g., Stephen Choi, Market Lessons for Gatekeepers, 92 Nw. U. L. REV. 916, 93449 (1998) (advocating an intermediate market-based due diligence regime for gatekeepers); Victor P. Goldberg, Accountable Accountants: Is Third-Party Liability Necessary?, $17 \mathrm{~J}$. LEGAL STUD. 295, 312 (1988) (advocating against third-party liability for auditors and arguing that reputation provides a sufficient incentive for auditors to detect fraud).

6 See Ronald J. Gilson \& Reinier H. Kraakman, The Mechanisms of Market Efficiency, 70 VA. L. REv. 549, 618-21 (1984) (explaining how investment bankers' positive reputations can help create a more efficient market).

${ }^{7}$ Issuer liability might be suboptimal either because issuer wrongdoing was too expensive for gatekeepers to detect or because issuers did not have adequate resources to make credible claims regarding the accuracy of their disclosures.

${ }^{8}$ See, e.g., Joshua Ronen, Post Enron-Reform, Financial Statement Insurance, and GAAP Revisited, 8 STAN. J.L. Bus. \& FIN. 39 (2002) (advocating system of financial statement insurance provided by third parties).

${ }^{9}$ Indeed, if issuers had adequate reputational incentives, there would be no demand for the gatekeeping function, and no need to address gatekeeper liability. No scholar has 
empirical matter, as Professor Coffee sets forth in great detail, ${ }^{10}$ gatekeepers have not done so. Instead, gatekeepers have performed their screening function abysmally during the past decade, in part as the natural outgrowth of recent regulatory and market changes.

In addition, there has emerged an unrebutted theoretical argument that gatekeepers might rationally decide to deplete their reputational capital (just as they would deplete any other capital asset) in an attempt to maximize expected profits. ${ }^{11}$ Gatekeeper reputations are important, but not in the simplistic way scholars previously have assumed. Instead, reputation is one of many assets in a gatekeeper's portfolio. If buyers of securities find it too costly to determine on their own whether an issue is worth the price, or if an issuer finds it too costly to convince buyers that the issuer's information is accurate, a reputable gatekeeper might be able to bridge that gap. Of course, gatekeepers will not necessarily find it economically rational to engage in reputation-depleting activities; that decision will depend on reputational markets, which are in flux. The central theoretical point is that reputational arguments related to gatekeepers are complex and reputation alone is not necessarily a viable constraint on gatekeeper certification.

If reputation alone is a suboptimal constraint-as there are reasons to believe it is, at least intermittently-investors and issuers could, in principle, be made better off by regulation that imposed additional constraints on gatekeeper conduct. It is potential failure in the reputational markets for gatekeeper services that motivates Professor Coffee's and my gatekeeper liability proposals.

There is one final area of agreement worth noting: Professor Coffee and I both support a strict liability regime for gatekeepers, not a negligence regime. ${ }^{12}$ In doing so, we are following the standard law-and-economics arguments favoring strict liability under certain circumstances, including where adjudicating fault is costly. ${ }^{13}$ But instead of revisiting those arguments, which

explained why disclosure arguments that do not work for issuers might nevertheless work for gatekeepers. See Partnoy, supra note 3, at 499-505 (setting forth seven factors for comparing issuers and gatekeepers).

${ }^{10}$ See Coffee, supra note 1, at 311-18 (providing evidence of gatekeeper failures with an emphasis on security analysts and auditors); see also John C. Coffee, Jr., Understanding Enron: "It's About the Gatekeepers, Stupid", 57 Bus. LAw. 1403, 1419 (2002) (setting forth similar arguments in the context of Enron's collapse and explaining that "Enron is more about gatekeeper failure than board failure").

11 See Coffee, supra note 1, at 326 (theorizing that it may be "more profitable for firms to realize the value of their reputational capital by trading on it in the short-run than by preserving it forever").

${ }^{12}$ Leading scholars in the area previously have supported a due diligence, or fault-based, regime. See, e.g., Choi, supra note 5, at 918-19 (supporting a market-based due diligence regime); Kraakman, Gatekeepers, supra note 1, at 98-100 (discussing the merits of a due diligence regime for underwriters).

13 This argument holds that strict liability is superior to negligence, because-put in this 
are addressed at length elsewhere, ${ }^{14}$ the remainder of this article will address Professor Coffee's proposal and analysis.

\section{REgulation vS. CONTRACT}

First, Professor Coffee claims ${ }^{15}$ that he refuses to incorporate private contracting into his proposal for three reasons, ${ }^{16}$ which I will label antitrust, cyclicality, and cost. In a nutshell, Professor Coffee's criticisms are that if private parties are allowed to contract, they will select a suboptimally low level of gatekeeper liability.

The antitrust component of this objection is that, because the gatekeeping industry is highly concentrated ${ }^{17}$ (e.g., there remain only the "Final Four" major audit firms), it is unlikely they would "compete vigorously and accept liability significantly above any minimum required threshold." 18 In other words, accounting firms - and perhaps other gatekeepers-would collude to keep their contracted minimum liability specifications low.

Professor Coffee is correct that, historically, when gatekeepers have been presented with an array of liability standards, they have been very effective in agreeing on a single standard. It is not clear, however, whether the convergence is due to competition or collusion. The same firms have dominated the gatekeeping function for decades, yet competition as to certain variables, such as price, can be vigorous. Some commentators have argued that gatekeeper competition as to liability would generate a range of optimal standards. ${ }^{19}$

But whatever the level of collusion among gatekeepers, encouraging gatekeepers to compete as to an additional variable-the minimum percentage of an issuer's liability they would assume-would not likely exacerbate any

context-strict liability forces a gatekeeper to take measures to prevent issuer misconduct without requiring a costly inquiry into whether the gatekeeper satisfied inexact standards of conduct (i.e., reasonable care or due diligence defenses). See STEVEN SHAVELl, ECONOMIC ANALYSIS OF ACCIDENT LAW 8-9 (1987) (explaining that under strict liability, a court needs not inquire into the socially optimal level of care or the level of care actually taken).

${ }^{14}$ See, e.g., Assaf Hamdani, Gatekeeper Liability, 77 S. CAL. L. REV. 53, 102-06 (2003) (assessing strict liability versus negligence regimes for gatekeepers); Partnoy, supra note 3, at 510-16 (explaining costs associated with due-diligence based securities liability regime).

15 I say "claims" because, in one sense, Professor Coffee's proposal embraces private contracting by permitting parties to contract for insurance. See infra p. 369.

${ }^{16}$ Coffee, supra note 1 , at $350-51$.

17 The gatekeeping function is not a purely competitive one. The oligopolistic industrial structure is due in part to the fact that the number of gatekeepers must be small, so that each one has sufficient assets at stake to make credible their claim of certifying issuer statements. Allowing gatekeepers to contract for liability would not reinforce those structural features.

18 Id. at 351.

19 See Choi, supra note 5, at 952-54 (asserting that, if gatekeepers competed as to liability, they would create multiple standards tailored for particular market needs). 
anticompetitive problem. ${ }^{20}$ Indeed, with respect to the accounting industry, the key motivating factor for allowing contracting is to enable firms outside the "Final Four" to compete by encouraging competition as to a new variable. Moreover, because the minimum percentage would be disclosed in public documents, it would more likely be the subject of competition than other variables (such as hourly rates, number of professionals assigned, or scope of the project) that are not disclosed. Thus, the minimum percentage would more likely affect issuer share prices-and thus encourage competitive bidding-in a way other undisclosed variables do not.

Notwithstanding Professor Coffee's antitrust objection, he nevertheless incorporates a private contracting element in his proposal by permitting parties to insure against liability. He proposes "to convert the gatekeeper into the functional equivalent of an insurer, who would back its auditor's certification with an insurance policy that was capped at a realistic level."21 If a gatekeeper decided that it could obtain a competitive advantage by raising the cap and purchasing more insurance, Professor Coffee apparently would pernit it to engage in such contracting. In this way, his proposal would employ contractual elements.

Second, Professor Coffee's cyclicality objection is that investors might not care about the level of gatekeeper liability during a bubble. Specifically, the argument is that during a bubble - and perhaps more generally - investors find the details of financial statements and footnotes too complex to understand. However, in contrast to the detailed financial information investors seemed to have ignored during the past few years, the minimum percentage level of gatekeeper liability is a heuristic that provides a simple check: one number shows how strongly the gatekeeper is willing to support an issuer's statements and practices.

More fundamentally, one should not reject a proposal merely because it would be ineffective at certain times. If investors would pay attention to minimum liability percentages during periods of relative calm, the policy would be worthwhile. It might be the case that no policy initiative will work during a bubble. Professor Coffee's proposal might be preferable from a cyclicality perspective, at least at certain times, because expected liability would depend on gatekeeper revenues, which increase during bubbles. Expected liability also would increase during the last stages of a bubble.

Third, Professor Coffee argues that issuers may have little incentive to bargain for high gatekeeper liability for two cost-related reasons: (1) high gatekeeper liability would not meaningfully reduce the issuer's liability, and (2) managers might prefer a low percentage because it would be easier to persuade a gatekeeper with low expected liability to tolerate risky practices.

${ }^{20}$ Even if gatekeepers did collude to select a percentage lower than the one participants in a well functioning market would have chosen, they could go below a specified minimum floor.

${ }^{21}$ Coffee, supra note 1, at 349. 
The first argument really is an assumption about how issuers and gatekeepers might contract. It might be the case that gatekeepers would not agree to assume much of the issuer's liability, in which case Professor Coffee would be correct. But issuers instead might find that gatekeepers-or other insurers-are an efficient way to apportion liability. Either way, even if the issuer's liability does not change, the amount of its payment for that liability will decline if the gatekeeper has agreed to a higher percentage. Any asset disparity between firms is of little consequence; indeed, one advantage of gatekeeper liability is that gatekeepers can credibly commit that they will have adequate assets even after an issuer's fraud is revealed, when the issuer's assets-and market capitalization-will be substantially depleted.

The second argument is a more serious one, and is the primary reason why gatekeepers should not be permitted to contract for any low level of liability, including zero. ${ }^{22}$ It is unclear whether manager-gatekeeper contracting would be a race to the top or a race to the bottom. Requiring issuers to disclose the gatekeeper's liability percentage might encourage optimal contracting. It might also reduce the adverse selection problem, discussed at the end of Part II. On the other hand, managers instead might effectively bribe gatekeepers with high fees today and low expected liability in the future.

But Professor Coffee's proposal-indeed any liability proposal-faces the same quandary. Unfortunately, agency costs are endemic, both within issuers and gatekeepers, and among them. Ultimately, a liability proposal will require a willingness to test the elasticity of manager behavior. Assuming it is possible to influence manager-gatekeeper behavior, the question becomes which minimum liability specification-revenues or percentages-creates better incentives for efficient gatekeeper monitoring, given these agency costs. This topic is addressed in the next Part.

\section{ReVenue Multiple Vs. Percentage of Damages}

The second basic difference between the two proposals is that Professor Coffee would base the gatekeeper's liability on a multiple on the highest annual revenues received from the client, whereas I would specify a minimum percentage of the client's ultimate liability. ${ }^{23}$ Essentially, Professor Coffee concludes that because the potential liabilities are astronomical, it would be too costly to force gatekeepers to internalize the costs of wrongdoing through higher fees. He argues that a revenues multiple would be a preferable liability cap because it would be less likely to lead to gatekeeper bankruptcies and would be more politically saleable.

There are four problems associated with capping gatekeeper liability based

${ }^{22}$ The second argument is presumably also the reason Professor Coffee's revenues multiple would not be zero.

${ }^{23}$ Professor Coffee also articulates a third difference-that my proposal would more frequently lead to gatekeeper bankruptcy-but this argument is essentially a variation on the second one: the basic question is whether the expected liability will be too high. 
on a multiple of revenues. First, damages based on revenues would measure only private costs to gatekeepers, not social costs, and therefore would either underdeter or overdeter, depending on the relationship between gatekeeper revenues and overall shareholder damages. Second, calculating a revenues multiple is fraught with technical difficulties. Third, Professor Coffee's assertions as to the scope of gatekeeper liability under a percentage measure are not supported by available facts. Fourth, having a regulator dictate a minimum liability cap would exacerbate the adverse selection problem gatekeepers face by preventing them from engaging in price discrimination as to liability.

First, although Professor Coffee posits a deterrence rationale, based on requiring that the expected punishment cost to the gatekeeper exceed the expected gain, he would not require that gatekeeper liability track social cost. In general, the deterrence perspective suggests that the expected penalty should equal the expected social harm. ${ }^{24}$ Professor Coffee's proposal, however, would focus only on the private gains and losses of the gatekeepers, not on those of society.

For example, the revenues proposal would have the perverse effect of making gatekeepers liable to disgorge a multiple of their revenues from a particular issuer, regardless of the magnitude of the fraud. Whether the issuer engages in a scheme that generates $\$ 100$ of harm or $\$ 100$ million of harm, the issuer still would be liable for a multiple of revenues. Such a regime would create incentives for perverse, suboptimal behavior; gatekeepers would take too much care with respect to schemes with small damages, and too little care with respect to schemes with large damages.

Second, calculating the "revenue" measure would be far from a simple task, and gatekeepers would have incentives to minimize the measure. Questions and ambiguities abound. Is revenue a gross or net number? Which expenses are included? What constitutes revenue-is it merely audit fees, or does it include other consulting income from that issuer? Whatever the definition, gatekeepers will have incentives to minimize the relevant revenue number, to minimize their liability, just as issuers would have the opposite incentive. Bargaining over revenue might result in a fair compromise, but the process would be complex and costly.

In addition, what would be the correct revenue multiple? Should the regulator take into account the term structure of interest rates, which would affect how large the multiple must be to deter gatekeepers weighing the expected liability cost against the discounted present value of a stream of revenue? What period of time should form the basis for the calculations? What if the revenue the gatekeeper received has been volatile-for example, what if the gatekeeper received only small payments for several years, but then

24 See Gary S. Becker, Crime and Punishment: An Economic Approach, 76 J. POL. ECON. $169,170,180$ (1968) (asserting that social harm must be considered in formulating social policy). 
received a very large fee that coincided with the issuer's fraud? Will the multiple vary itself over time, based on changes in the market environment? If the effect of bubbles is relevant, as Professor Coffee claims, should the multiple be cyclical based on investor psychology?

In contrast, a percentage measure has the advantage of simplicity. The gatekeeper's liability would be linked to the actual amount of damages the issuer pays, either in a settlement or judgment. Although that amount certainly would vary, along with the variables described above, calculating a percentage of that amount will remain simple and straightforward. Moreover, a measure established by the market has advantages over a measure established by regulators. There is some risk that regulators will get the revenue multiple wrong, based on a misunderstanding of key variables, or that they will not update the multiple to account for rapidly changing and complex industry practices. A percentage measure is flexible, ${ }^{25}$ and varies with changes in the market.

Third, Professor Coffee asserts that liability under my proposal will be too high, citing an example of a $\$ 100$ billion loss. This example is misplaced, and is not consistent with available facts. First, a decline in market capitalization of $\$ 100$ billion will not necessarily—or even likely—lead to liability of $\$ 100$ billion. Indeed, no case has generated such a large award or settlement, and one does not seem likely, even in the Enron litigation. Settlements of more than several hundred million dollars are rare.

As the table below indicates, ${ }^{26}$ average settlements in securities class action cases recently have been in the $\$ 15$ to $\$ 25$ million range. The largest settlement, in the Cendant litigation, was much higher than the next largest settlements.

\section{$\underline{\text { Securities Class Action Settlements }}$}

\begin{tabular}{|c|c|c|c|}
\hline & $\underline{2000^{*}}$ & $\underline{2001}$ & $\underline{2002}$ \\
\hline Minimum & $\$ 100,000$ & $\$ 100,000$ & $\$ 400,000$ \\
\hline Median & $\$ 5,800,000$ & $\$ 5,500,000$ & $\$ 6,800,000$ \\
\hline Average & $\$ 17,000,000$ & $\$ 14,700,000$ & $\$ 24,300,000$ \\
\hline Maximum & $\$ 490,000,000$ & $\$ 259,000,000$ & $\$ 490,000,000$ \\
\hline Total & $\$ 1,342,000,000$ & $\$ 4,400,000,000$ & $\$ 2,400,000,000$ \\
\hline
\end{tabular}

${ }^{25}$ Parties could fashion custom-tailored deductibles or staggered percentages in the same way parties to reinsurance contracts do.

${ }^{26}$ See Securities Class Action Settlements, at http://securities.cornerstone.com/ pdfs/LES\%20YIR.pdf (last accessed Feb. 10, 2004) (providing securities class action settlement statistics for 2001 and 2002); Securities Class Action Settlements, at http://securities.cornerstone.com/pdfs/yir_Settle.pdf (last accessed Feb. 10, 2004) (providing securities class action settlement statistics for 2000 and 2001). 
Of course, lawsuits pending now are likely to lead to settlements (or judgments) even larger than that in the Cendant litigation. But even the most aggressive estimates have put the total liability associated with recent corporate scandals at less than $\$ 100$ billion. Professor Donald C. Langevoort estimated in early 2003 that bankers faced a total expected liability of $\$ 20$ to $\$ 25$ billion from civil lawsuits related to the recent financial frauds. ${ }^{27}$

A minimum percentage measure of, say, five percent of these amounts would not have bankrupted the leading gatekeepers. Yes, the expected liability would be substantial, as would be warranted. But in the future, the percentage could be set so that the minimum expected liability of gatekeepers would not increase. Any increases in expected liability would be due to private contracting, with the gatekeepers' agreement. Gatekeepers would not necessarily oppose such a strict liability regime-indeed, it might reduce their expected liability compared to the current fault-based system.

Neither do the data support Professor Coffee's assertion that liability would be substantially less if it were based on a multiple of revenues. According to one recent study of 1240 U.S. companies, the average annual audit fee was $\$ 1.3$ million (compared to the average consulting fee of $\$ 3.2$ million) ${ }^{28}$ Assuming these figures are correct, imposing liability on audit firms of ten times their annual revenues would roughly match the current liability regime (expected damages of $\$ 13$ million based on audit fees alone or an additional $\$ 32$ million based on consulting fees, as compared to average settlements in recent cases in the $\$ 15$ to $\$ 25$ million range). Aggregate numbers are a bit misleading because some issuers pay much larger fees-tens of millions of dollars. But if one assumes that high revenues are correlated with high settlements, damages of ten-times-revenue would be roughly comparable to actual settlements in recent years.

The key difference between the proposals is not aggregate or average expected liability - it is the composition of that liability. A revenues metric would skew liability in individual cases: damages would be higher where the fraud was minor or the gatekeeper played no significant role and lower where the fraud was substantial or the gatekeeper played a major role. In other words, the gatekeeper's liability would not match the size of the fraud. In particular, a revenues-based proposal would not permit very substantial awards, regardless of the gatekeeper's role. Even in the Enron litigation, gatekeeper liability would be capped at a few hundred million dollars,

${ }^{27}$ See Alissa Schmelkin, Chase Reserve: Some See Floor, Others a Ceiling, AM. BANKER, Jan. 10, 2003, at 1 (discussing banks' setting aside of reserves to cover future litigation costs).

${ }^{28}$ Gretchen Morgenson, On Reform, It's Time to Walk the Walk, N.Y. TIMES, Oct. 6, $2002, \S 3$, at 1 (discussing corporations' failure to use separate auditing and consulting firms and the need for corporations to regain investors' trust). See James Flanigan, Andersen's Pain Will Strengthen System, L.A. TIMES, Mar. 24, 2002, Business, at 1 (citing average audit fee for U.S. businesses of about $\$ 2$ million per year). Underwriting and other investment banking fees are higher. 
depending on the precise revenue measure used.

If Professor Coffee prefers less liability, he easily could achieve that result by lowering the minimum percentage threshold in my proposal. A revenues metric does not necessarily generate lower expected liability than a percentage metric. The advantage to a percentage metric is that it tracks social cost, whereas a revenues metric does not.

Fourth, Professor Coffee's proposal would exacerbate the adverse selection problem gatekeepers face. Issuers and gatekeepers face information asymmetry: issuers have private information about their expected liability; it is too expensive for gatekeepers to police issuers to uncover this information, and issuers cannot credibly claim to gatekeepers that they have disclosed all such information. As a result, gatekeepers charge a fee based on the average expected liability costs, not the expected liability of any individual issuer. ${ }^{29}$

However, to the extent gatekeepers uncover information about their expected liability for a particular issuer, they could-in theory-discriminate based on price, and thereby minimize the adverse selection problem. Although accountants might not be able to detect fraud, they can detect indicia of fraud that would lead them to reduce their expected liability exposure (or increase their fees) in response to evidence that an issuer would more likely be found liable in a future fraud case. ${ }^{30}$ There is evidence that gatekeepers adjust prices in response to perceived changes in expected liability. ${ }^{31}$

Gatekeepers facing a liability regime based on a multiple of revenues would find it more difficult to price discriminate. Gatekeepers might want to increase their revenues for risky issuers, but doing so would increase their expected liability. In contrast, a percentage measure is not linked to revenues. A gatekeeper suspecting issuer fraud would find it easier to price discriminate under a liability system based on a percentage metric than one based on a revenues metric.

29 See George A. Akerlof, The Market for "Lemons": Quality Uncertainty and the Market Mechanism, 84 Q.J. ECON. 488, 490-91, 495-96 (1970) (discussing the market costs of dishonesty).

${ }^{30}$ For example, Ernst \& Young LLP received warnings about an accounting scheme to overstate profits at client HealthSouth Corp. nearly a year before the scheme was uncovered. Although the audit partners could not confirm that the scheme was occurring when they received the warnings, the warnings themselves would have been relevant to an assessment of Ernst \& Young's liability exposure. See Carrick Mollenkamp \& Ann Carrns, Ernst Received Warning on HealthSouth Results, WaLl St. J., Apr. 24, 2003, at A2 (discussing Ernst \& Young's receipt of an e-mail alleging fraud at HealthSouth).

31 See, e.g., Ronald A. Dye, Auditing Standards, Legal Liability, and Auditor Wealth, 101 J. POL. ECON. 887, 908 (1993) (finding that accounting firms incorporate expected liability into their pricing decisions). 


\section{CONCLUSION}

Since the 1980s, the standard scholarly argument about gatekeeper liability has focused on reputation. Recently, Professor Coffee and others have demonstrated that reputation alone is a suboptimal constraint. Scholars are now moving beyond reputation to debate how to create incentives for optimal gatekeeper conduct.

The key question is: what type of liability system should apply to gatekeepers? The current fault-based regime is costly and ineffectual. But strict liability alone would be a draconian response, which would overdeter and make the gatekeeping function unprofitable.

Professor Coffee and I seek an intermediate response: strict liability for gatekeepers, with limits. The key to our proposals is the creation of a reinsurance market for securities fraud risks, where gatekeepers would behave more like insurers. There are a variety of ways to do this. Professor Coffee favors the use of caps based on a multiple of the gatekeeper's revenues; I prefer limiting gatekeeper liability through contracting based on a percentage of the issuer's liability.

I have tried to demonstrate in this article that a percentage limitation is superior to a revenues multiple cap. But as to the more fundamental issue, Professor Coffee clearly has it right: the prior literature on gatekeepers was based on assumptions about reputational constraints that have now proven untenable. 
BOSTON UNIVERSITY LAW REVIEW 